\title{
KONSENTRASI MERKURI DALAM KOLAM LIMBAH PENCUCIAN LOGAM
}

\author{
Mercury Concentration In Metal Washing Pool Waste Ponds
}

\author{
Irawati Mei Widiastuti ${ }^{1,2}$, Asus Maizar Suryanto Hertika ${ }^{2}$, Muhammad Musa², \\ Diana Arfiati ${ }^{2}$ \\ ${ }^{1}$ Fakultas Peternakan dan Perikanan, Universitas Tadulako, Palu, Indonesia \\ ${ }^{2}$ Fakultas Perikanan dan Ilmu Kelautan, Universitas Brawijaya, Malang, Indonesia \\ irakarno88@gmail.com
}

\begin{abstract}
ABSTRAK
Merkuri digunakan sebagai pengikat emas dan dilepaskan ke lingkungan perairan yang menyebabkan pencemaran. Konsentrasi merkuri pada limbah pencucian emas harus diminimalkan sehingga tidak berbahaya bagi perairan. Salah satu caranya adalah dengan mengendapkan limbah.. Penelitian ini bertujuan untuk mendeteksi konsentrasi merkuri dan kualitas air pada setiap kolam penampungan secelum limbah dibuang ke perairan. Kolam penampungan limbah sebanyak enam kolam (P1, P2, P3, P4, P5, P6) dengan satu kolam air bersih (P0). Merkuri dideteksi menggunakan Atomic Absorption Spectrophotometry (AAS), kualitas air yang diukur adalah suhu, $\mathrm{pH}$, dan warna air limbah. Data hasil penelitian dianalisis secara deskriptif. Konsentrasi merkuri di semua kolam pengendapan antara 0,021 $\pm 0,002 \mathrm{mg} / \mathrm{L}$ hingga 0,051 $\pm 0,005 \mathrm{mg} / \mathrm{L}$ ). Penurunan rata-rata konsentrasi merkuri dari kolam P1 ke P6 adalah 16,7\%. Konsentrasi merkuri telah melebihi batas maksimum yang diperbolehkan untuk merkuri di air. Suhu pada setiap kolam mengalami penurunan dari kolam P1 sampai P6, namun $\mathrm{pH}$ meningkat.
\end{abstract}

Kata kunci: merkuri, limbah, pencemaran perairan

\section{ABSTRACT}

Mercury is used as a gold binder and released into the aquatic environment that causes pollution. The concentration of mercury in gold washing wastes must be minimized so that it is not harmful to the waters. One way is to precipitate waste. This study aims to detect mercury concentrations and water quality in each reservoir pool before waste is discharged into the water. The waste pool is six pools (P1, P2, P3, P4, P5, P6) with one pool of clean water (PO). Mercury was detected using Atomic Absorption Spectrophotometry (AAS), the water quality measured was temperature, $p H$, and color of wastewater. The research data were analyzed descriptively. The concentration of mercury in all settling ponds was between $0.021 \pm 0.002 \mathrm{mg} / \mathrm{L}$ to $0.051 \pm 0.005 \mathrm{mg} /$ $L)$. The decrease in the average mercury concentration from pond P1 to P6 is $16.7 \%$. The concentration of mercury has exceeded the maximum allowed for mercury in water. The temperature in each pond has decreased from pond P1 to P6, but pH has increased. Keywords: mercury, waste, water pollution 


\section{PENDAHULUAN}

Salah satu sumber daya alam yang sampai sekarang masih banyak dieksplorasi adalah hasil tambang terutama emas karena merupakan sektor yang menjadi andalan untuk mendapatkan devisa negara. Penambangan emas merupakan kegiatan yang banyak dilakukan oleh masyarakat di Indonesia yang memberikan dampak positif dan negatif (Agus, Sukandarrumidi, \& Wintolo, 2005). Teknik penambangan yang digunakan adalah amalgamasi yang menggunakan merkuri sebagai pengikat emas (Raivel, Syarfina, Puspita, Apriajum, \& Prima, 2016). Teknik tersebut menimbulkan dampak negatif bagi lingkungan (Rhani, 2012) karena melepaskan limbah merkuri yang membahayakan ekosistem dan kesehatan (Dash, Mangwani, \& Das, 2014). Pada proses amalgamasi, merkuri terlepas ke lingkungan pada tahap pencucian. Limbah yang mengandung merkuri dibuang langsung ke badan air atau ke atas tanah (Rhani, 2012). Beberapa kasus pencemaran merkuri telah terjadi di Indonesia termasuk penurunan kualitas air di Desa Jendi Wonogiri Jawa Tengah (Agus et al., 2005), di Kabupaten Bombana Sulawesi Tenggara (Raivel, Syarfina, Puspita, Apriajum, \& Prima,
2016), peningkatan konsentrasi merkuri di sungai Cikaniki Bogor (Juliawan, 2015), pencemaran sungai dan tanah di Desa Cisungsang Lebak Banten (Pamungkas, Thayib, \& Inswiasri, 2015).

Merkuri termasuk logam berat nonesensial yang beracun bagi organisme di atas konsentrasi tertentu (Nandan, Sankhla, Kumar, Agrawal, \& Kumari, 2016), konsentrasinya meningkat pada level yang mengkhawatirkan karena meningkatnya kegiatan antropogenik termasuk penambangan (Dash, Mangwani, \& Das, 2014). Kegiatan penambangan dan pengolahan emas menghasilkan limbah yang dibuang ke lingkungan. Limbah tersebut berbahaya bagi ekosistem. Oleh karena itu limbah harus diolah agar ketika dibuang ke perairan tidak menyebabkan pencemaran. Pemerintah telah mewajibkan setiap perusahaan yang menghasilkan limbah berat untuk mendaur ulang limbah hingga memenuhi standar mutu untuk dibuang ke aliran sungai maupun laut (Peraturan Pemerintah No. 82 Tahun 2001). Salah satu metode pengurangan merkuri di air limbah yaitu metode pengendapan sampai tingkat konsentrasi yang rendah dengan menggunakan senyawa karbonat, phosphat atau sulfida, sedangkan proses yang banyak dilakukan adalah 
pengendapan sulfida dan proses koagulasi atau co-presipitasi (Said, 2010).

Penggunaan merkuri untuk mengikat emas dilakukan pula di Gempol Pasuruan Jawa Timur, namun telah dilakukan penurunan konsentrasi merkuri dengan menampung limbah dalam kolam pengendapan. Berdasarkan metode yang telah dilakukan, diperlukan informasi penurunan konsentrasi merkuri pada setiap kolam pengendapan. Tujuan studi ini adalah untuk menguji konsentrasi merkuri dan kualitas air pada setiap kolam pengendapan sebelum dibuang ke perairan.

\section{METODE PENELITIAN}

Sampel diambil secara langsung dari enam (6) kolam (P1, P2, P3, P4, P4, P5, P6) penampungan dan pengendapan limbah dan satu (1) kolam penampungan air bersih (P0). Kolam penampungan P1 merupakan kolam pertama yang menampung limbah dari pencucian emas, sedangkan kolam penampungan $\mathrm{P} 2, \mathrm{P} 3$, P4, P5 dan P6 merupakan kolam yang digunakan untuk mengendapkan limbah. Susunan kolam pengendapan secara seri, limbah dari kolam P1 dialirkan ke kolam P2, limbah P2 dialirkan ke kolam P3, limbah P3 mengalir ke kolam P4, limbah P4 mengalir ke kolam P5, limbah P5 dialirkan ke kolam P6. Limbah di kolam P6 dibuang ke perairan.

Sampel yang diuji dimasukkan ke dalam botol sampel $250 \mathrm{~mL}$ dan diuji konsentrasi merkurinya. Parameter kualitas air pada setiap sampel yang diuji meliputi derajat keasaman $(\mathrm{pH})$, suhu, oksigen terlarut (Dissolved Oxygen/DO) dan warna air (EPA, 2001).

$$
\text { Metode untuk pengukuran }
$$

konsentrasi merkuri $(\mathrm{Hg})$ menggunakan Atomic Absorption Spectrophotometry (AAS) dan kualitas air diukur menggunakan DO meter untuk oksigen terlarut, termometer untuk suhu dan $\mathrm{pH}$ meter untuk $\mathrm{pH}$, sedangkan warna air diamati secara visual. Data hasil pengukuran merkuri, suhu dan $\mathrm{pH}$ dibandingkan dengan baku mutu kualitas air (Peraturan Pemerintah No. 82 Tahun 2001 tentang Pengelolaan Kualitas Air dan Pengendalian Pencemaran).

Prosedur pengukuran merkuri dengan menggunakan metode AAS (EPA, 2007) sebagai berikut $50 \mathrm{~mL}$ sampel air dimasukkan ke dalam gelas piala dan ditambahkan $5 \mathrm{~mL} \quad \mathrm{HNO}_{3}$ pekat, dipanaskan perlahan sampai volumenya menjadi 15-20 mL. Kemudian ditambahkan $5 \mathrm{~mL} \quad \mathrm{HNO}_{3}$ pekat dan 
dipanaskan lagi. Dilanjutkan dengan penambahan asam dan dipanaskan sampai logam larut (sampel air menjadi jernih); 2 $\mathrm{mL} \quad \mathrm{HNO}_{3}$ pekat ditambahkan dan dipanaskan 10 menit, setelah itu didestruksi. Hasil destruksi diambil $10 \mathrm{~mL}$ dan ditambahkan $1 \mathrm{~mL} \quad \mathrm{KMnO}_{4} \quad 0,01 \mathrm{~N}$ dimasukkan ke dalam ASC sesuai dengan nomor urutnya. Hasil pengukuran dalam spektrofotometer serapan atom dengan panjang gelombang 253,6 nm langsung dinyatakan sebagai hasil logam.

\section{HASIL DAN PEMBAHASAN}

\section{Konsentrasi merkuri (Hg) pada kolam penampungan limbah}

Hasil pengujian menunjukkan konsentrasi merkuri pada kolam pengendapan P1 $(0,051 \pm 0,005 \mathrm{mg} / \mathrm{L})$ mengandung konsentrasi merkuri paling tinggi dibandingkan dengan kolam pengendapan yang lain. Sedangkan konsentrasi merkuri yang terkandung di dalam kolam pengendapan P6 $(0,021 \pm 0,002 \mathrm{mg} / \mathrm{L})$ paling rendah dibandingkan dengan kolam pengendapan yang lain. Pada kolam sumber air untuk pencucian mengandung merkuri (P0) sebesar 0,012 $\pm 0,002 \mathrm{mg} / \mathrm{L}$. Penurunan konsentrasi merkuri dari kolam P1 sampai P6 rata-rata sebesar 16,7\%. Proses pengendapan terjadi pada setiap kolam sehingga pada terjadi penurunan konsentrasi merkuri dari kolam pengendapan P1 sampai P6. Namun konsentrasi merkuri pada kolam pengendapan tidak berbeda dengan kolam yang digunakan sebagai sumber air (Figure1). Hal ini berkaitan dengan keberadaan merkuri di alam, bahwa merkuri secara alami sudah terdapat di lingkungan perairan, meskipun konsentrasinya kecil.

Kolam sumber air untuk mencuci emas mengandung merkuri karena letak dari kolam tidak jauh dari kolam pengendapan sehingga merkuri yang terdapat pada limbah dapat meresap ke dalam tanah dan sampai ke kolam. Apabila dibandingkan dengan baku mutu kualitas air (Peraturan Pemerintah Nomor 82 Tahun 2001) maka konsentrasi merkuri pada setiap kolam telah melebihi ambang batas maksimum yang direkomendasikan (0,002 $\mathrm{mg} / \mathrm{L})$. Limbah pada kolam P6 masih mengandung merkuri dengan konsentrasi di atas ambang maksimal karena cara mengendapkan limbah dalam kolam hanya bisa menurunkan konsentrasi merkuri dan tidak bisa menghilangkan. Merkuri di air dalam bentuk ion sehingga sulit untuk terikat. Merkuri yang digunakan untuk pengikat emas akan 
tercampur atau terpecah menjadi butiran- merkuri dari air termasuk presipitasi, butiran halus yang sulit dipisahkan pada adsorpsi, volatilisasi dan bioremediasi proses penggilingan sehingga pada proses namun tidak ada yang ada untuk pencucian merkuri terbawa masuk ke menghilangkan merkuri pada kisaran 1-10 perairan (Widowati, 2008). Ada beberapa ppt (EPA 2007).

metode alternatif untuk menghilangkan

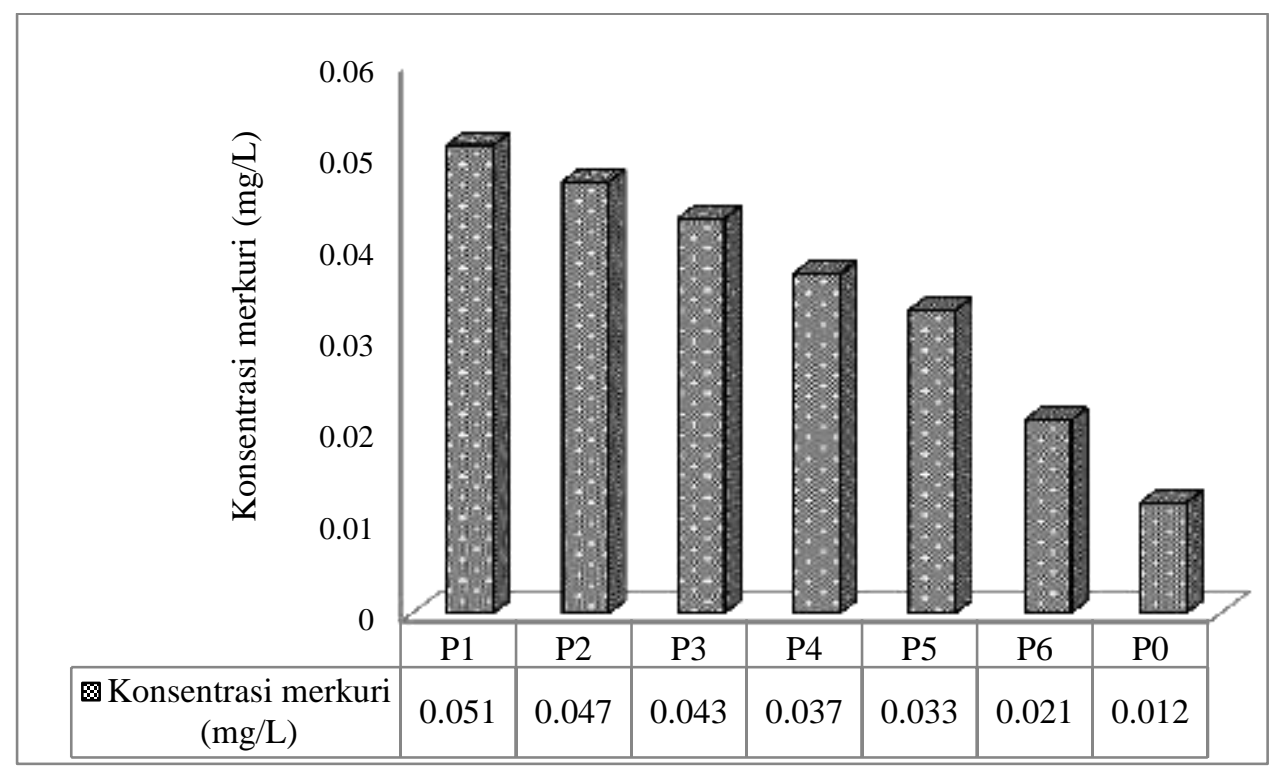

Gambar 1. Konsentrasi merkuri pada kolam penampungan limbah

Di alam, menurunnya kadar sehingga kadar merkuri dalam air tinggi merkuri dipengaruhi oleh faktor (Darmono, 2010). Curah hujan biasanya lingkungan, iklim dan musim. Aliran arus mengurangi konsentrasi $\mathrm{Hg}$ menjadi sungai memungkinkan mengurangi kurang dari 2 ppb namun membutuhkan konsentrasi merkuri sehingga partikel penambahan bahan kimia dan pemantauan merkuri bergerak mengikuti arus. Pada terus menerus (EPA, 2009). Selain itu, musim hujan, air menjadi pasang dan jarak sumber pencemar menentukan volume air bertambah sehingga konsentrasi ( $\mathrm{Hg})$ yang terakumulasi, konsentrasi merkuri menurun dan semakin dekat jarak maka semakin tinggi surutnya air pada musim kemarau pula konsentrasinya (Musthofa, Santi, \& menyebabkan konsentrasi merkuri di Ashar, 2016). Logam berat bersifat toksik sungai meningkat karena berkurangnya karena tidak bisa dihancurkan (nonpengenceran dan volume air sedikit degradable) dan organisme hidup yang 
ada di lingkungan sehingga logam-logam tersebut terakumulasi ke lingkungan, terutama mengendap di dasar perairan dan membentuk senyawa kompleks bersama bahan organik dan anorganik (Widowati, 2008).

\section{Kualitas air pada kolam penampungan} limbah

Kualitas air yang diamati pada penelitian ini meliputi derajat keasaman $(\mathrm{pH})$, suhu dan warna air. Pengukuran kualitas air di kolam penampungan limbah bertujuan untuk mengetahui perubahan suhu, pH dan warna air pada setiap kolam penampungan limbah sehingga dapat diketahui kelayakan limbah untuk dibuang ke perairan. Beberapa faktor yang mempengaruhi laju absorbsi logam berat yaitu suhu, $\mathrm{pH}$, oksigen terlarut, fraksi sedimen, adanya senyawa lain dan ukuran organisme (Darmono, 2010). Tabel 1 menunjukkan $\mathrm{pH}$ pada kolam P1 terrendah $(1,83 \pm 0,12)$ dibandingkan dengan kolam P2, P3, P4, P5 dan P6, sedangkan pada kolam P0 cenderung netral. Hal ini berkaitan dengan kandungan merkuri di dalam air. Suhu pada semua kolam penampungan berkisar antara $25,4 \pm 0,8^{\circ} \mathrm{C}-30,8 \pm 0,4^{\circ} \mathrm{C}$ dengan warna air yang bervariasi dari kuning sampai kuning coklat tua. Air di kolam P0 cenderung bening. Suhu kolam dipengaruhi oleh penetrasi sinar matahari. Pada saat penetrasi matahari sampai ke dasar kolam maka suhu akan meningkat sampai di dasar. Kolam penampungan terletak di luar dan langsung terkena sinar matahari.

Tabel 1. Kualitas air pada kolam penampungan limbah

\begin{tabular}{lccc}
\hline Kolam penampungan limbah & Suhu $\left({ }^{\circ} \mathrm{C}\right)$ & $\mathrm{pH}$ & Warna air limbah \\
\hline Kolam P1 & $30,8 \pm 0,4$ & $1,83 \pm 0,12$ & kuning coklat tua \\
Kolam P2 & $29,6 \pm 0,5$ & $2,13 \pm 0,21$ & kuning coklat \\
Kolam P3 & $29,8 \pm 1,4$ & $2,17 \pm 0,42$ & kuning tua \\
Kolam P4 & $29,1 \pm 1,7$ & $2,40 \pm 0,53$ & kuning tua \\
Kolam P5 & $28,7 \pm 2,3$ & $2,43 \pm 0,64$ & kuning tua \\
Kolam P6 & $25,4 \pm 0,8$ & $5,17 \pm 0,72$ & kuning \\
Kolam P0 & $23,1 \pm 0,7$ & $6,93 \pm 0,70$ & bening \\
\hline
\end{tabular}




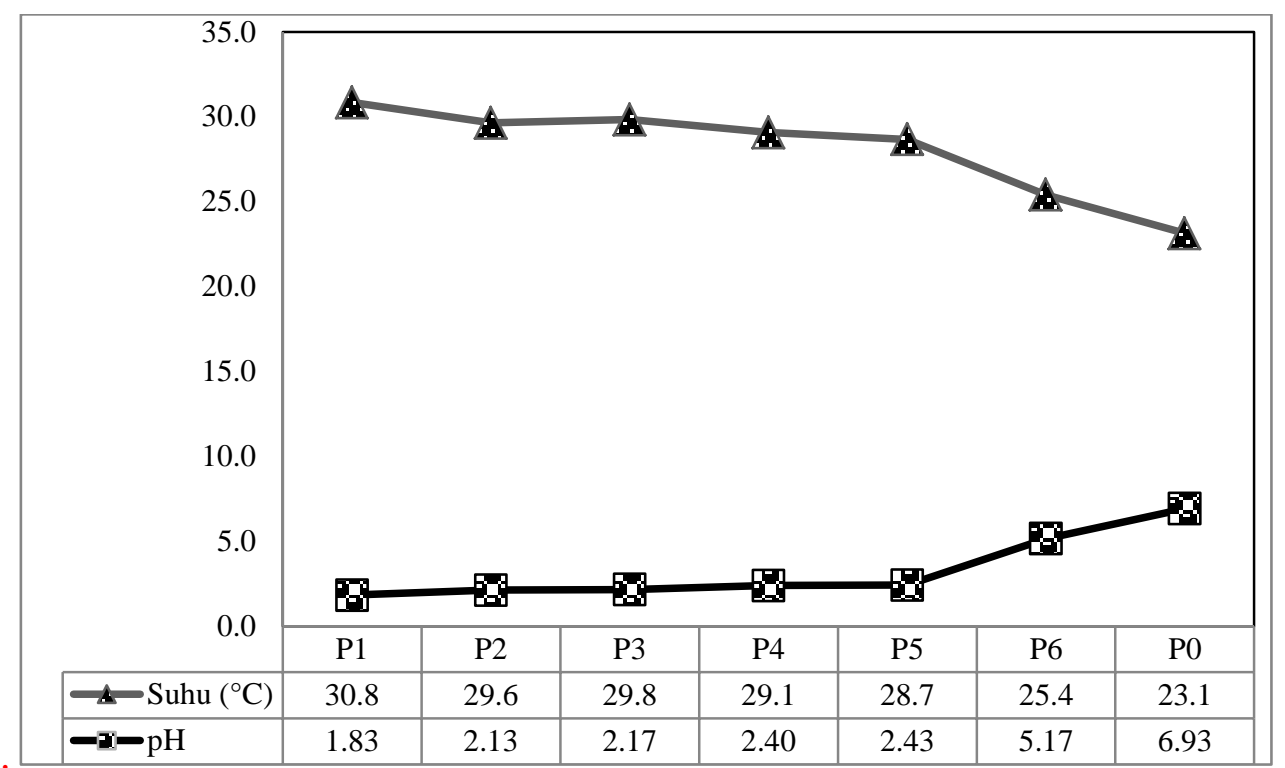

Gambar 2. Suhu dan pH air limbah pada kolam penampungan limbah pencucian emas

Gambar 2 menunjukkan terjadi penurunan suhu pada kolam pengendapan sampai pada kolam P6. Sebaliknya $\mathrm{pH}$ mengalami peningkatan ketika suhu limbah meningkat. Derajad keasaman (pH) mempengaruhi keberadaan logam merkuri dalam air sungai karena $\mathrm{pH}$ merupakan parameter penting dan efektif dalam proses adsorpsi (Tadkaew, Sivakumar, Khan, McDonald, \& Nghiem, 2010). Peningkatan pH dapat meningkatkan kapasitas adsorpsi merkuri (Palar, 2008), ketika $\mathrm{pH}$ rendah tingkat adsorpsi berkurang (Gao \& Campbell, 2014). Merkuri berubah menjadi $\mathrm{Hg}^{+2}$ pada $\mathrm{pH}$ 7, pada $\mathrm{pH}$ rendah tingkat adsorpsi berkurang dan ketika $\mathrm{pH}$ meningkat, $\mathrm{H}^{+}$menurun (Gao \& Campbell, 2014). Ketika pH air rendah, endapan di dasar kolam pada semua merkuri di perairan menjadi stabil, ketika $\mathrm{pH}$ naik dapat mengubah kestabilan bentuk karbonat menjadi hidroksida yang membentuk ikatan dengan partikel pada badan air sehingga menguap dan membentuk lumpur (Palar, 2008). Efek $\mathrm{pH}$ tidak hanya dipengaruhi oleh jenis ion tetapi dipengaruhi juga oleh sifat adsorben (Tadkaew, Sivakumar, Khan, McDonald, \& Nghiem, 2010). Peningkatan konsentrasi merkuri anorganik dan larutan konsentrasi ionik memiliki efek negatif pada proses adsorpsi (Yaghmaeian, Reza, Simin, Amir, Mahmood \& Shahrokh, 2015).

Warna limbah di kolam penampungan P1, P2, P3 lebih keruh daripada kolam P4, P5, P6 dan terjadi 
kolam pengendapan. Warna endapan berbeda pada setiap kolam dan warna endapan mempengaruhi warna limbah. Warna air terdiri dari sejumlah besar zat berwarna; asam fulvat, asam humat, koloid dan partikel (Stumm \& Morgan, 1981) (Liu, Cheng, Branco, \& Marra, 2017). Senyawa berwarna dari partikel dan agregat tidak mengandung jumlah merkuri yang sama per satuan warna sebagai senyawa kecil, namun tersebar merata di dalam badan air (Nilsson \& Håkanson, 1992).

\section{KESIMPULAN}

Konsentrasi merkuri di kolam penampungan dan pengendapan $\mathrm{P} 1$ tertinggi, namun mengalami penurunan rata-rata sebesar $16,7 \%$ pada kolam berikutnya (P2, P3, P4, P5 dan P6). Konsentrasi tersebut telah melebihi batas maksimal merkuri yang diperbolehkan terdapat di air. Suhu mengalami penurunan pada setiap kolam secara berurutan, namun $\mathrm{pH}$ meningkat ketika suhu menurun.

\section{DAFTAR PUSTAKA}

Agus, C., Sukandarrumidi, \& Wintolo, D. (2005). The Impact of Liquid Woste of Gold Processing on the River Water Quality and the Method for Minimizing the Impnct by Using Zeolite Case Study of the Traditionol Gold Mine in Jendi
Wllage District Selogiri Wonogiri Sub Province Central Java Province, Indon. Manusia Dan Lingkungan, 12(1), 13-19.

Darmono. (2010). Lingkungan Hidup dan Pencemaran : Hubungannya dengan Toksikologi Senyawa Logam. Jakarta: UI Press.

Dash, H. R., Mangwani, N., \& Das, S. (2014). Characterization and potential application in mercury bioremediation of highly mercuryresistant marine bacterium Bacillus thuringiensis PW-05. Environmental Science and Pollution Research, 21(4), 26422653.

https://doi.org/10.1007/s11356013-2206-8

EPA. (2001). Parameters of Water Quality: Interpretation of Water Quality, 133.

EPA. (2007). Inductively Coupled Plasma-Atomic Emission Spectrometry, 34 .

EPA. (2009). Potential Export of Mercury Compounds from United States for Conversion to Elemental Mercury - Report to Congress, 123. https://doi.org/ISSN:0377-9424 / 2007

Gao, K., \& Campbell, D. A. (2014). Photophysiological responses of marine diatoms to elevated $\mathrm{CO} 2$ and decreased $\mathrm{pH}$ : a review. Functional Plant Biology, 41(5), 449. https://doi.org/10.1071/fp13247

Juliawan N. (2005). Laporan Pendataan Penyebaran Unsur Merkuri pada Wilayah Pertambangan di daerah Cibaliung, Kabupaten Pandeglang, Provinsi Banten. Bandung (ID) : 
Pusat Sumber Daya Geolog

Liu, Y., Cheng, Z., Branco, B. F., \& Marra, J. F. (2017). Speciation and Mobility of Phosphate in the Eutrophic Ponds at Prospect Park, Brooklyn, New York, USA. Journal of Geoscience and Environment Protection, 05(06), 26-36.

https://doi.org/10.4236/gep.2017.5 6004

Musthofa, S., Santi, D. N., \& Ashar, T. (2016). Analisis kandungan merkuri $(\mathrm{Hg})$ pada air sumur gali masyarakat di sekitar penambangan emas tradisional Desa Saba Padang Kecamatan Huta Bargot Kabupaten Mandailing Natal Tahun 2015.

Nandan, M., Sankhla, M. S., Kumar, R., Agrawal, P., \& Kumari, M. (2016). Heavy Metals Contamination in Water and their Hazardous Effect on Human Health-A Review. International Journal of Current Microbiology and Applied Sciences, 5(10), 759-766. https://doi.org/10.20546/ijcmas.20 16.510 .082

Nilsson, Å., \& Håkanson, L. (1992). Relationships between mercury in lake water, water colour and mercury in fish. Hydrobiologia, 235-236(1), 675-683. https://doi.org/10.1007/BF0002625 6

Palar H. (2008). Pencemaran dan Toksikologi Logam Berat. Jakarta: Rineka Cipta.

Pamungkas, H. S. R., Thayib, H., \& Inswiasri. (2015). Potential Distribution Pattern of Artisanal Gold Mining ' S Mercury Waste in Cisungsang Village, Lebak
District , Banten. Jurnal Ekologi Kesehatan, 14(3), 195-205.

Peraturan Pemerintah Nomor 82 Tahun 2001 tentang Pengelolaan Kualitas Air dan Pengendalian Pencemaran.

Raivel, S., Puspita, D., Apriajum, M., \& Prima. E. (2016). Analisis kadar zat merkuri yang digunakan pada area tambang emas rakyat desa wumbubangka kecamatan rarowatu utara kabupaten bombana provpinsi sulawesi tenggara. Proceeding Seminar Nasional Kebumian Ke-9.

Rhani, H. C. (2012). Faktor - Faktor Yang Berhubungan Dengan Kadar Merkuri (Hg) Pada Tanah Pemukiman Warga Di Sekitar Lokasi Penambangan Emas Tradisional (Studi Kasus Di Desa Jendi, Kecamatan Selogiri, Kabupaten Wonogiri, Provinsi Jawa Tengah). Fkm Undip, 1 .

Said, N. I. (2010). Metoda Penghilangan Logam Merkuri di Dalam Air Limbah Industri. Jai, 6(1), 136148.

Stumm, W. and Morgan, J.J. (1981) Aquatic Chemistry: An Introduction Emphasizing Chemical Equilibria in Natural Waters. 2nd Edition, John Wiley \& Sons Ltd., New York.

Tadkaew, N., Sivakumar, M., Khan, S. J., McDonald, J. A., \& Nghiem, L. D. (2010). Effect of mixed liquor $\mathrm{pH}$ on the removal of trace organic contaminants in a membrane bioreactor. Bioresource Technology, 101(5), 1494-1500. https://doi.org/10.1016/j.biortech.2 009.09.082

Yaghmaeian, K., Khosravi Mashizi, R., 
Nasseri, S., Mahvi, A. H., Alimohammadi, M., \& Nazmara, S. (2015). Removal of inorganic mercury from aquatic environments by multi-walled carbon nanotubes. Journal of Environmental Health Science and Engineering, 13(1), 1-9. https://doi.org/10.1186/s40201-
015-0209-8

Widowati. (2008). Efek Toksik Logam Pencegahan dan Penanggulangan. Penerbit. Andi Yogyakarta 